\title{
Diagnosis and identification of Leishmania species in patients with cutaneous leishmaniasis in the state of Roraima, Brazil's Amazon Region
}

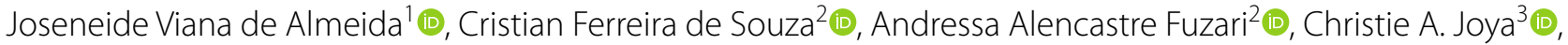
Hugo O. Valdivia ${ }^{3}$, Daniella Castanheira Bartholomeu ${ }^{4} \mathbb{D}$ and Reginaldo Peçanha Brazil ${ }^{*}$

\begin{abstract}
Background: Cutaneous leishmaniasis $(\mathrm{CL})$ is an endemic disease in Brazil that is highly prevalent in the northern region of the country. Although there is a continuous and growing number of cases registered in the state of Roraima, there is limited information regarding the species of Leishmania that affect the human population. In this study, we aimed to characterize which Leishmania species cause human disease in those presenting with cutaneous leishmaniasis in endemic areas of the State of Roraima.

Methods: We conducted a prospective surveillance study between 2016 to 2018 in health centers located in the State of Roraima, Brazil. Participants with clinical suspicion of $\mathrm{CL}$ were enrolled and provided lesion samples for parasitological detection by microscopy. A subset of the samples was tested by polymerase chain reaction and sequencing of the internal transcribed spacer 1 (ITS-1 PCR) for molecular species identification.

Results: A total of 262 participants were enrolled in this study. Of those, 129 (49.27\%) were positive by parasitological examination. Most positive subjects (81.58\%) were male, and most cases presented a single lesion (80.26\%). ITS-1 PCR and sequencing on a subset of 76 samples allowed us to detect nine different species of Leishmania: L. (V.) braziliensis, L (V.) panamensis, L. (V.) guyanensis, L. (V.) naiffi, L. (V.) shawi, L.(V.) utingensis, L. (V.) lindenbergi, L. (L.) amazonensis and L. (L.) mexicana.

Conclusions: Our study provides the first assessment of circulating species of Leishmania in the State of Roraima, Brazil, and shows the high diversity in this region. This study opens the path for further research on the transmission of leishmaniasis in the northernmost Brazilian State including vector and reservoir surveillance as well as for intensification of investigation and control activities against $\mathrm{CL}$ in the region.
\end{abstract}

Keywords: Cutaneous leishmaniasis, Leishmania spp., Molecular diagnosis, PCR

\section{Introduction}

Leishmaniasis is a complex of diseases caused by species of intracellular protozoa, morphologically similar, of the genus Leishmania (Kinetoplastida: Trypanosomatidae) and transmited by the bite of infected female sand flies

*Correspondence: brazil.reginaldo@gmail.com

${ }^{2}$ Laboratório de Doenças Parasitárias, Instituto Oswaldo Cruz/Fundação Oswaldo Cruz, Rio de Janeiro, RJ, Brazil

Full list of author information is available at the end of the article
(Diptera: Psychodidae) [1]. The disease is highly prevalent in poor countries and vulnerable populations with limited access to health services [2]. In 2017, $94 \%$ of all new cases reported to the WHO occurred in seven countries: Brazil, Ethiopia, India, Kenya, Somalia, South Sudan and Sudan, and approximately $90 \%$ of mucocutaneous leishmaniasis cases occurred in Bolivia, Brazil and Peru [3].

Leishmaniasis is highly prevalent in the northern region of Brazil where it accounts for a large proportion 
of cases each year [3]. The Brazilian Amazon is in this area [3, 4] and is comprised of municipalities of large territorial extension and difficult access. This scenario poses challenges to implement measures recommended by the Brazilian Ministry of Health for the control of $\mathrm{CL}$ and is further complicated by the multiple ethnic, cultural and environmental factors that characterize this region $[4,5]$. Previous studies have shown that Brazil's Amazon region has undergone profound environmental changes resulting from mining, agriculture and livestock expansion [6], which may be contributing to changes and maintenance of the leishmaniasis cycle in the area. The State of Roraima, which is in this region, has experienced these changes with an increase of leishmaniasis cases between 2011 to 2015 [3]. Recorded data on CL cases through the Ministry of Health's Information System for Notifiable Diseases (SINAN) [7] between the years 2008 to 2018 revealed that the average number of cases reported in Roraima was 3477 cases per year.

Studies describing the epidemiological profile of the disease in Roraima have shown that the majority of reported cases are in men, of working age and migrants involved in activities such as deforestation and occupation of areas such as settlement projects [8]. The predominant clinical form of the disease is cutaneous with one single lesion; regarding treatment, most of these patients were discharged for healing [3].

To understand CL transmission in the State of Roraima, the present study focused on identifying CL in patients from the public health network of Roraima as well as performing molecular diagnosis by PCR (polymerase chain reaction) and sequencing for Leishmania species determination. The results obtained provide information that will help to develop measures for interventions and efficient control strategies for human CL in the state.

\section{Materials and methods Study area}

The State of Roraima was created in 1988 and belongs to the North region of Brazil. The state shares borders to the south with the State of Amazonas, to the East with the Republic of Guyana and the State of Pará and to the West with the State of Amazonas and Venezuela. It has a territorial area of $224,299 \mathrm{~km}^{2}$ that is divided into 15 municipalities: Alto Alegre, Amajarí, Boa Vista (Capital), Bonfim, Cantá, Caracaraí, Caroebe, Iracema, Mucajaí, Normandy, Pacaraima, Rorainópolis, São João da Baliza, São Luiz and Uiramutã (Fig. 1) [9]. The estimated population is 605,761 inhabitants including Venezuelan immigrants [10].

\section{Patient selection and sample collection}

The study included patients with suspected CL that were enrolled between 2016 to 2018 at the Reference Laboratory of the Mecejana Health Center and at the Indian Health House (CASAI) in Boa Vista and different Health Units in the municipalities of Mucajaí, Caroebe (southern region of Roraima state) and Pacaraima on the border with Venezuela. Patients were informed about the research and provided informed consent. A clinical examination was performed in all patients and a questionary was administered to collect socioeconomic and demographic data (sex, age group), presence of lesions, previous leishmaniasis episodes and treatment history.

Samples were collected from these patients by scraping of the lesion for microscopy. Remaining tissue was used to prepare filter paper imprints for molecular detection of Leishmania species. The study was approved by the ethics committee of the Federal University of Roraima under protocol number CAAE 57445116.3.0000.5302.

\section{Parasitological analysis}

Direct examination was performed by collecting tissue at the edge of the ulcerated lesion using an aseptic technique with a lancet and/or sterile scalpel. The material was spread onto microscopy slides, fixed with methanol and stained with Giemsa and/or Panotic. The slides were read using optical microscopy at $100 \times$ magnification [1].

\section{Molecular studies}

After collecting the samples on filter paper, DNA extraction was performed using the Gentra Puregene Tissue Kit $\left(\right.$ QIAGEN $\left.^{\circledR}\right)$, following the manufacturer's protocol. PCR of the internal transcribed spacer 1 was performed using primers LITSR (5'CTGGATCATTTTCCGATG3') and L5.8S (5'TGATACCACTTATCGCACTT3') as previously described [11].

The PCR reaction was prepared under the following buffer conditions: $1 \times$ buffer solution $(200 \mathrm{mM}$ Tris- $\mathrm{HCl}$ pH8.4, $500 \mathrm{mM} \mathrm{KCl}$ ), $1.5 \mathrm{mM} \mathrm{MgCl}_{2}, 0.2 \mathrm{mM}$ mixture dNTPs, 0.5 pmol of the LITSR primer, 0.5 pmol of the L5.8S primer, $1 \mathrm{U}$ of Taq Platinum polymerase DNA (Invitrogen ${ }^{\circledR}$ ) and $5 \mu$ l of template DNA, in a final volume of $25 \mu \mathrm{l}$. The amplification reaction was carried out by 33 cycles of denaturation at $95^{\circ} \mathrm{C}$ for $30 \mathrm{~s}$, annealing at $53^{\circ} \mathrm{C}$ for $1 \mathrm{~min}$ and extension at $72^{\circ} \mathrm{C}$ for $1 \mathrm{~min}$ in an automatic DNA thermocycler (MaxyGene Gradient, AXYGENE ${ }^{\circledR}$ ). The reaction generates a fragment of approximately 350 bp, which was analyzed on a $2 \%$ agarose gel stained with GelRed $^{\mathrm{TM}}$ and compared with controls of $L$. (V.) braziliensis (MHOM/BR/75/M2903). 


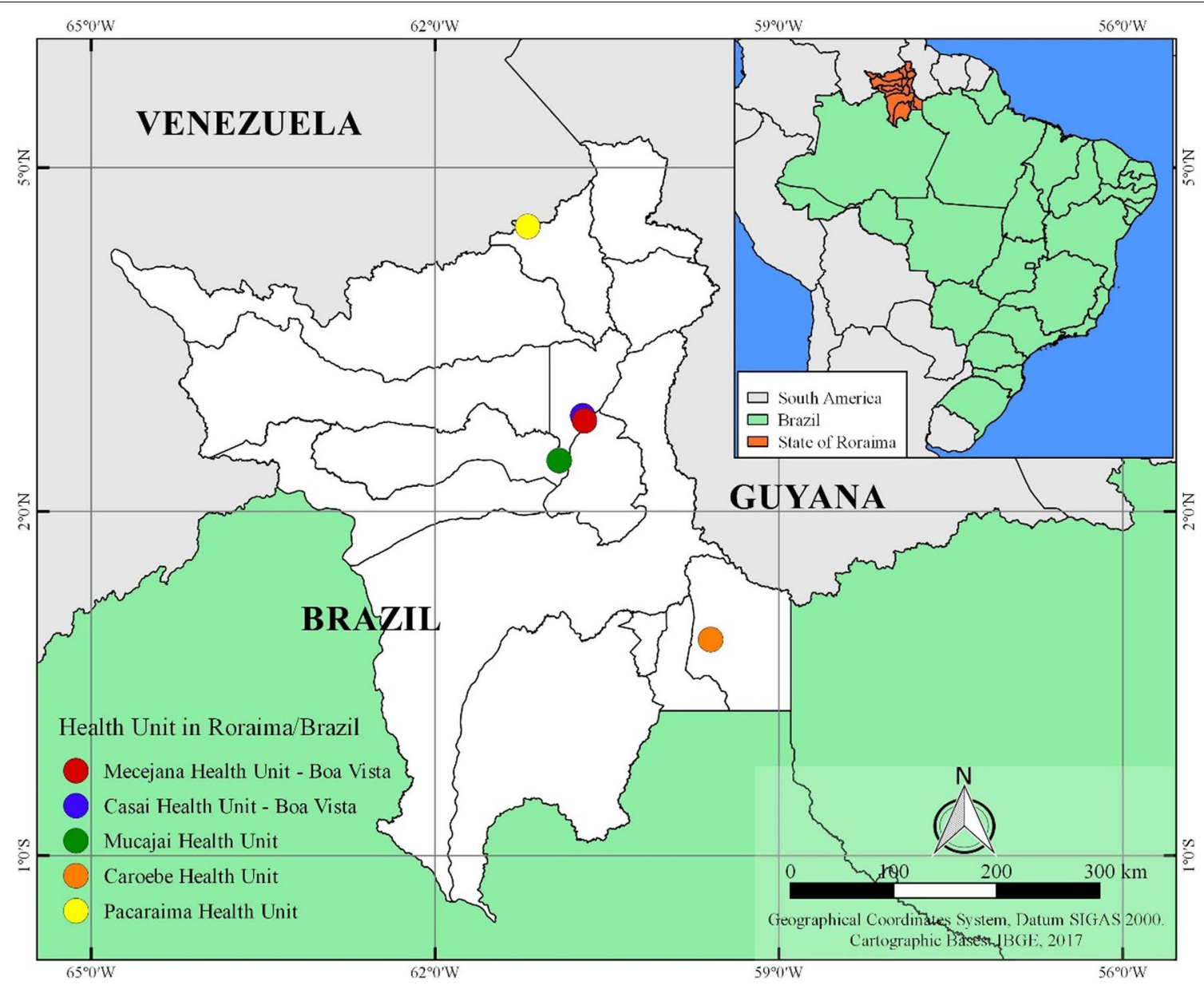

Fig. 1 Distribution of collection sites according to municipalities of Roraima. The inset shows in the left the number of samples collected as part of this study at each laboratory. The map on the right side shows the location of the State and the study sites

PCR-positive samples were sent to Macrogen ${ }^{\circledR}$ (Seoul, Korea) for bidirectional Sanger gene sequencing using an automatic sequencer (Applied Biosystems 3730XL). The obtained sequences were aligned and analyzed using the Sequencher ${ }^{\circledR} 4.1 .4$ program and subsequently compared by BLAST and deposited in GenBank (sample ID: MT606220-MT606276) [12].

\section{Data analysis}

To provide additional confirmation to the species detected by Blast, the resulting Fast sequences were used for discriminant analysis of principal components. Briefly, reference sequences from $L$. (V) panamensis PSC1, L. (V) braziliensis (LH2215), L. (L) amazonensis (M2269) and L. (L) mexicana (LEM2284) strains were downloaded and aligned with the clinical sequences from our study using Clustal omega [13].

The resulting multiple sequence alignment was loaded into R using the package "ape" [14] and cleaned prior to genetic analysis using the package "poppr" in order to secure that only high quality data remains [15]. The parameter used excluded positions with $>30 \%$ missing calls. DAPC was performed on the cleaned dataset using the R "adegenet" package [16]. Data obtained in the study were organized into a Microsoft Excell $2013^{\circledR}$ spreadsheet and used for data analysis in GraphPad Prism 5.0 software (GraphPad Software Inc., San Diego, CA, USA). Due to the categorical nature of the samples, data were analyzed using the chi-square test $\left(\mathrm{x}^{2}\right)$ on BioEstat 5.0 [17] with a significance level of $95 \%(\alpha=0.05)$.

\section{Results}

In the period between 2016 and 2018, 262 samples were collected from patients with suspected CL in the municipalities of Boa Vista, Mucajaí, Caroebe, Pacaraima and CASAI in Roraima (Fig. 1). Parasitological and PCR tests showed that 129 samples $(49.27 \%)$ were positive for Leishmania sp. (Fig. 2). Of these samples, a subset of 76 samples were sent for sequencing. 


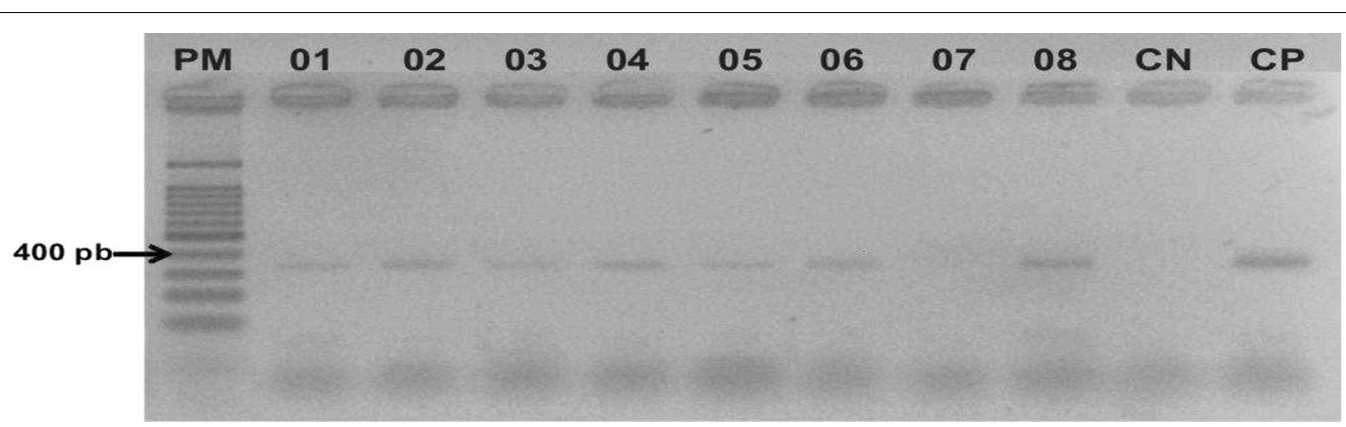

Fig. 2 PCR results of Leishmania spp. on filter papers of suspected CL patients in Roraima in 2\% agarose gel stained with Red gel. PM: base pair marker (100bp); CN: negative control (pure DNA-free water); CP: positive control of Leishmania braziliensis (MHOM/BR/75/M2903); 07: negative sample; 01-06 and 08: positive samples

Sequencing results allowed the identification of Leishmania species distributed in nine municipalities in the state of Roraima.

Of 76 patients, $67(88.16 \%)$ were from rural areas and 9 (11.84\%) from urban settings (Tables 1 and 2). In the analysis regarding the gender distribution, $81.58 \%(n=$ 62 ) of all cases were in men (Table 1). All patients presented the clinical cutaneous form with the following distribution of lesions: $80 \%(n=61)$ with a single lesion, $9 \%$ $(n=7)$ with two lesions and $11 \%(n=8)$ with three or more lesions. In the assessment by age group the highest percentage of cases occurred in patients between 21 to 40 years $(60.5 \%, n=46)$.

This study detected six of the seven species of Leishmania found by the Ministry of Health to cause CL in Brazil. In addition, we also observed the occurrence of $L$. (L.) mexicana and $L .(V)$ panamensis (Table 2).

The PCA provided further support to the GenBank results and was fully able to cluster most clinical samples with their species reference sequences (Fig. 3). In this regard, nine out of ten putative $L$. (V.) panamensis samples clustered with the $L$. (V.) panamensis PSC1

Table 1 Distribution of Leishmania species identified in the sequencing of the material obtained by PCR-ITS-1 by sex, age, area of origin and nationality in the State of Roraima, Brazil, from 2016 to 2018

\begin{tabular}{|c|c|c|c|c|c|c|c|c|c|c|c|c|c|c|c|}
\hline \multirow[t]{2}{*}{ Patient/variables } & \multirow{2}{*}{$\begin{array}{l}\text { Number of } \\
\text { samples }\end{array}$} & \multirow[t]{2}{*}{1 lesion } & \multirow[t]{2}{*}{2 lesions } & \multirow[t]{2}{*}{$\geq 3$ lesions } & \multirow[t]{2}{*}{ DNA $(+)$} & \multicolumn{10}{|c|}{ Leishmania species identified by sequencing } \\
\hline & & & & & & L.b & L.a & L. $g$ & L.p & L.S & L.I & L.u & L. sp. & L. $n$ & L.m \\
\hline \multicolumn{16}{|l|}{ Gender } \\
\hline Male & 62 & & & & & & & & & & & & & & \\
\hline Female & 14 & & & & & & & & & & & & & & \\
\hline \multicolumn{16}{|l|}{ Age range } \\
\hline 0 to 10 & 4 & 4 & & & 4 & 2 & & & 1 & & & & 1 & & \\
\hline 11 to 20 & 6 & 5 & & 1 & 6 & & 2 & & 1 & 2 & & & 1 & & \\
\hline 21 to 30 & 18 & 13 & 2 & 3 & 18 & 5 & 4 & & 4 & 1 & 1 & & 3 & 1 & \\
\hline 31 to 40 & 28 & 20 & 5 & 2 & 28 & 11 & 4 & 3 & 3 & & & & 6 & & \\
\hline 41 to 50 & 13 & 13 & & 1 & 13 & 3 & 3 & & 1 & & & 1 & 5 & & \\
\hline$\geq 51$ & 7 & 6 & & 1 & 7 & 2 & 2 & 1 & & & & & 2 & & \\
\hline \multicolumn{16}{|l|}{ Area } \\
\hline Urban & 9 & 6 & 2 & 1 & 9 & 3 & 2 & & 1 & & & & 3 & & \\
\hline Rural & 67 & 56 & 5 & 6 & 67 & 20 & 12 & 4 & 9 & 3 & 1 & 1 & 15 & 1 & 1 \\
\hline \multicolumn{16}{|c|}{ Origin By nationality } \\
\hline Brazil & 71 & 60 & 7 & 7 & 71 & 23 & 14 & 4 & 11 & 3 & 1 & 1 & 13 & 1 & \\
\hline Venezuela & 3 & 3 & 0 & 0 & 3 & 0 & 1 & & & & & & 2 & & \\
\hline Guyana & 2 & 2 & 0 & 0 & 2 & 0 & & 1 & & & & & 1 & & \\
\hline Indigenous & 6 & 3 & 1 & 2 & 6 & 3 & & & 2 & 1 & & & & & \\
\hline
\end{tabular}

L.b = Leishmania braziliensis; L. $a=$ Leishmania amazonensis; L.g = Leishmania guyanensis; L.p = Leishmania panamensis; L. $s=$ Leishmania shawi; L.I = Leishmania lindenbergi; L. u = Leishmania utingensis; L. sp. = Leishmania sp.; L. $n=$ Leishmania naiffi; L.m= Leishmania mexicana. 
Table 2 Distribution of Leishmania species identified by OTS1 sequencing according to the municipality of origin of patients

\begin{tabular}{|c|c|c|c|c|c|c|c|c|c|c|}
\hline Municipalities/Country & L. b & L. a & L.g & L. n & L.S & L.p & L.u & L. sp. & L. I & L.m \\
\hline \multicolumn{11}{|l|}{ Species } \\
\hline Boa Vista & 3 & 2 & & & & & & 4 & & \\
\hline Alto Alegre & 7 & & 2 & & & 3 & & & 1 & 1 \\
\hline Cantá & & 5 & & 1 & & & & & & \\
\hline Caroebe & 1 & 1 & 1 & & 2 & & & 4 & & \\
\hline Mucajaí & 3 & 1 & & & & & 1 & & & \\
\hline Iracema & 2 & 1 & & & & & & & & \\
\hline São Luiz & & 1 & & & & & & & & \\
\hline Pacaraima & & 1 & & & & 2 & & 4 & & \\
\hline Amajarí & 8 & & & & 1 & 5 & & 2 & & \\
\hline Pres. Figueredo - AM & & & & & & & & 1 & & \\
\hline Guyana & & & 1 & & & & & 1 & & \\
\hline Venezuela & & 1 & & & & & & 2 & & \\
\hline TOTAL & 24 & 13 & 4 & 1 & 3 & 10 & 1 & 18 & 1 & 1 \\
\hline
\end{tabular}

L.b = L. braziliensis; L. $a=$ L. amazonensis; L.g = L. guyanensis; L.p =L. panamensis; L.S = L. shawi; L.I = L. lindenbergi; L. u = L. utingensis; L. sp. $=$ Leishmania sp.; L.n =L. naiff; L.m = Leishmania mexicana

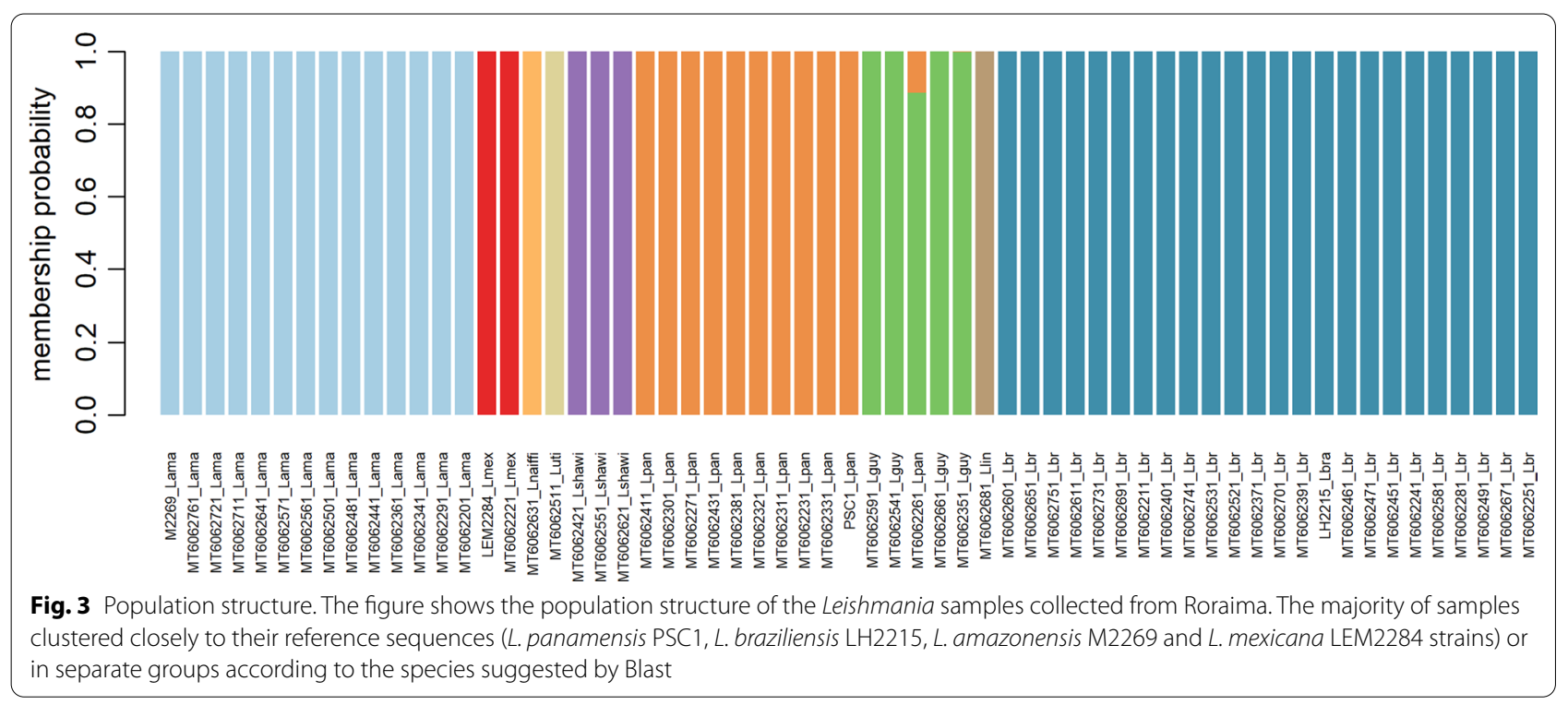

reference whereas the remaining sample (MT6062261) clustered with the $L$. (V.) guyanensis samples. In addition, the $L$. (L.) mexicana, L. (V.) braziliensis and L. (L.) amazonensis clinical samples clustered with their respective reference sequences $L$. (L.) mexicana (LEM2284), L. (V.) braziliensis (LH2215) and L. (L.) amazonensis (M2269). Furthermore, $L$. (V.) naiff, $L$. $(V$ ) shawi, L. (V) lindernbergi and $L .(V)$ utingensis presented separate clusters supporting their GenBank identification (Fig. 3)
L. $(V)$ braziliensis was the most frequent species in our samples accounting for $31.6 \%$ of the 76 samples $(n=24)$, followed by $L .(L)$ amazonensis with $17.0 \%(n=13), L .(V)$ panamensis with $13.2 \%(n=10), L .(V)$ guyanensis with $5.3 \%(n=4), L .(V)$ shawi with $3.9 \%(n=3)$ and $L .(V)$ naiffi, $L .(V)$ utingensis, $L$. $(V)$ lindenbergi and $L$. (L) mexicana with $1.31 \%(n=1)$ each. The remaining samples $(n=$ $18,23.7 \%$ ) presented profiles without specific identification.

Regarding the Leishmania species identified in the municipalities of Roraima, we observed that $31.38 \%$ ( $n$ 
$=24)$ were $L$. (V.) braziliensis present in samples from patients in the municipalities of Boa Vista, Alto Alegre, Caroebe, Mucajaí, Iracema and Amajarí, (Table 2). L. (L.) amazonensis was identified as the second most characterized species in this study in $18.4 \%(n=14)$ of the samples, distributed in the municipalities of Cantá, Boa Vista, Alto Alegre, Caroebe, Mucajaí, São Luiz and Amajarí and in Venezuela with one case. In $13.15 \%(n=10)$ of the samples, $L$. (V.) panamensis was distributed in the municipalities of Amajarí, Pacaraima and Alto Alegre. In $6.57 \%(n=5)$ of the samples L. (V.) guyanensis was detected in the municipalities of Alto Alegre and Caroebe and in Guyana. L. (V.) shawi was identified in 3.94\% $(n=3)$ of the samples from the municipalities of Caroebe and Amajarí. L. (V.) naiffi was identified in a patient sample from the municipality of Cantá, $L .(V$.) utingensis was detected in an individual residing in the municipality of Mucajaí, and $L$. (V.) lindenbergi and $L$. (L.) mexicana were detected in Alto Alegre with one case for each species.

\section{Discussion}

The study showed that, although most positive cases were from residents in Brazil, we had cases of patients residing in Guyana and Venezuela. In this regard, reports from the health professionals who attended the patients showed that many individuals come from neighboring countries and cross the border with Brazil in search of diagnosis and treatment.

The study also revealed six positive cases in indigenous subjects of different ethnic groups, corroborating the work of Pezente who described the epidemiological profile of CL in the State of Roraima between the years 2007 and 2016 [8]. That study showed an incidence of CL of $13 \%$ in indigenous populations, demonstrating the need for further studies to understand the impact of CL in this population.

In the present study, most patients with clinical suspicion of $\mathrm{CL}$ were in people living in rural areas. The rate of positivity for Leishmania was higher in males and in the age group between 21 and 40 years old, which represented $60.3 \%$ of cases $(n=46)$. This is an important finding, since this demographic group represents most of the economically active population.

This case profile is like those observed in a previous epidemiological study conducted in the state [15], which observed that most cases occured in people between 31.6 to 34.5 years old $[18,19]$. The results also demonstrate a predominance of single CL lesions, which is in accordance with other studies conducted in the Amazon [19, 20] and Pará [21].
Regarding the distribution by municipalities, our study showed that all cases were distributed in 9 of the 15 municipalities in the state of Roraima. Although cases covered all the State microregions [9], > 55\% of them were concentrated in the municipalities of the Boa Vista microregion. This could be related to the fact that this region has active mining areas and is among the first entry points for immigrants coming from Venezuela.

Our GenBank and PCA results provide support for the introduction of $L .(V)$ panamensis in Brazil as well as the potential introduction of $L$. (L.) mexicana. The presence of one $L$. (V.) panamensis sample that clustered closer to $L$. (V.) guyanensis requires additional confirmation by other methods such as multilocus sequence typing or next generation sequencing. Furthermore, additional analyses are needed to confirm the finding of $L$. (V.) naiffi, $L$. (V.) shawi, L.(V) lindernbergi and L. (V) utingensis because of the lack of whole genomes or reference sequences from these species.

A subset of sequenced samples $(n=18)$ was not identified to the species level and remained as Leishmania sp. These sequences presented a low quality, which limited subsequent alignment, blast and PCA analysis.

Our study showed that most cases were due to $L$. $(V$.) braziliensis, which was identified in $31.6 \%(n=24)$ of the samples. In Brazil, this species is the main causative agent of CL with a recent report of expansion in the Amazon [22, 23]. Our findings suggests that this species may be circulating and causing the disease in all municipalities in the State, as it was identified in at least one municipality of each micro-region. This assumption is supported by a previous study on phlebotomine fauna in the municipality of Caroebe [24] in the southern part of the state where Lutzomyia davisi was the most abundant species in the primary forest. This sand fly species has been found naturally infected with $L$. (V.) braziliensis in several locations in the Brazilian Amazon [25].

Leishmania (L) amazonensis was the second most identified species and was detected in the municipalities of Boa Vista, Alto Alegre, Cantá, Caroebe, Mucajaí, São Luiz and Amajarí and in Venezuela. As observed in other states of the Amazonian region [19, 22], this species has an important role in public health, since it is associated with diffuse cutaneous leishmaniasis (DCL), which induces anergy in the individual's immune cell response. In addition, there have been reports of mucosal cases caused by this parasite species $[1,26]$. The presence of Lutzomyia flaviscutelata in Serra do Tepequém of the Municipality of Amajarí [5] reinforces the transmission of $L$. (L) amazonensis in this region as observed in the Brazilian Amazon [27]. 
In the case of $L$. (V.) guyanensis, there are previous reports of the presence of its vector, Lutzomyia (Nyssomyia) umbratilis, in Serra do Tepequém in Amajarí [5], and it is known that this species has a wide distribution in areas of primary forest in the Amazon Region. Although infrequent, the occurrence of Lutzomyia (Nyssomyia) umbratilis in Serra do Tepequém should be a warning sign, since contact with this species in forest areas generally results in the transmission of Leishmania (V.) guyanensis to humans.

The presence of $L$. (V.) guyanensis in samples in the cities of Alto Alegre, Caroebe and in Guyana supports this finding and demonstrates that this species may be circulating on a larger scale in the state. Clinically, individuals affected by this species may present single or multiple lesions, the latter being more frequently due to several vector bites or lymphatic metastases, with the possibility of lymphangitis [28]. This species was also identified in mucosal lessions in the state of Rondônia [29] expanding the possibility of mucosal clinical presentation.

Our study reports for the first time the presence of $L$. (V.) panamensis in Roraima with the detection in the municipalities of Alto Alegre, Pacaraima and Amajarí, located in the northern region of the state. L. (V) panamensis is the main causative agent of cutaneous leishmaniasis in Panama [30] and Colombia and is responsible for a relatively large number of cases in other neighboring countries with records of approximately 3000 new cases per year [31].

We also detected the presence of $L$. (V.) shawi in two human cases. This species was detected in monkeys from the species Cebus appela and Chiropotes satanus, sloths Choloepus didactylus and Bradypus tridactylus, procyonid Nasua nasua and in the sand fly Lutzomyia whitmani, all of them from primary forest areas of the State of Pará [32].

The presence of $L$. (V.) naiffi in human CL cases in Roraima complements previous reports from the States of Amazonas [33, 35] and Pará [34], which indicates that this species is not uncommon in the region.

Two other species of Leishmania that were detected in this study were L. (V.) utingensis and L. (V.) lindenbergi, which accounted for one case each. $L(V)$ utingensis was first reported in 1977 from an infected Lutzomyia tuberculata from the Brazilian State of Pará [36]. The scarcity of data on this species as causative $\mathrm{CL}$ agent in humans underscores the need of further research to characterize this species.

$L$. $(V)$ lindenbergi was reported in soldiers deployed in forested areas in the City of Belém of the Brazilian State of Pará [37] and more recently in two CL cases in the state of Rondonia [38]. In the study, we also observed the occurrence of Leishmania (L.) mexicana, which is a species commonly found in Central America and in the northern region of South America [26].

\section{Conclusions}

We provide evidence that several Leishmania species are present in the State of Roraima infecting local people as well as foreign and Brazilian migrants that are circulating not only in the state but also in the Amazon region. These results are important as they open an opportunity for additional research related to disease incidence, treatment responses, circulating reservoirs and vectors, which are key components for the development of effective control programs.

\section{Abbreviations}

LC: Cutaneous leishmaniasis; SINAN: Information System for Notification of Complaints; PCR: Polymerase chain reaction; WHO: World Health Organization; MS: Ministry of Health; PDL: Direct parasitological examination; CASAI: Indian health home; LCD: Diffuse cutaneous leishmaniasis.

\section{Acknowledgements}

We thank the Health Centers Mecejana, Casai (indigenous health home of Roraima), in the municipality of Boa Vista and the health centers in the municipalities of Caroebe, Pacaraima and Mucajaí that treated patients with suspected leishmaniasis and these patients who agreed to be included in the study.

\section{Disclaimer}

The views expressed in this article are those of the authors and do not necessarily reflect the official policy or position of the Department of the Navy, Department of Defense, or the US Government.

\section{Copyright}

Several authors of this paper are employees of the US Government. This work was prepared as part of their official duties. Title 17 U.S.C. §105 provides that 'Copyright protection under this title is not available for any work of the United States Government.'Title 17 U.S.C. \$101 defines a US Government work as a work prepared by a military service member or employee of the US Government as part of that person's official duties.

\section{Authors' contributions}

JVA and RPB: Conceptualized the study, data acquisition, analysis and interpretation of data. JVA, RPB and CFS wrote original draft of the manuscript. JVA, CFS and AAF: Performed the investigation, analysis and interpretation of data. RPB provided supervision and validate the study. CAJ, HOV and DCB provide resources and reviewed the English. All authors assisted visualization of the study. All authors read and approved the final manuscript.

\section{Funding}

This work was funded by CAPES through the DINTER in Parasitic Biology at UFRR with FIOCRUZ. Aid No. 1647/2018. Case number: 23038.013815 / 201864. This work was supported by the US DoD Armed Forces Health Surveillance Branch and its Global Emerging Infections Surveillance section (AFHSB/GEIS), PROMIS ID P0143_19_N6_03, 2019-2020.

\section{Availability of data and materials}

All data generated or analyzed during this study are included in this article and its additional file. Raw data are available upon request to the corresponding author.

\section{Ethical approval and consent to participate}

The study was approved by the ethics committee of the Federal University of Roraima under the number CAAE 57445116.3.0000.5302. All patients signed an informed consent form. 


\section{Consent for publication \\ Not applicable.}

\section{Competitive interests}

The authors declare that they have no competing interests.

\section{Author details}

1 Programa de Pós-Graduação em Biologia Parasitária, Instituto Oswaldo Cruz/ Fundação Oswaldo Cruz, Rio de Janeiro, RJ, Brasil. ${ }^{2}$ Laboratório de Doenças Parasitárias, Instituto Oswaldo Cruz/Fundação Oswaldo Cruz, Rio de Janeiro, RJ, Brazil. ${ }^{3}$ Department of Parasitology, US Naval Medical Research Unit 6, Lima, Peru. ${ }^{4}$ Departamento de Parasitologia, ICB, Universidade Federal de Minas Gerais, Belo Horizonte, Minas Gerais, Brazil.

\section{Received: 27 June 2020 Accepted: 11 December 2020} Published online: 07 January 2021

\section{References}

1. Brasil. Ministério da Saúde. Secretaria de Vigilância em Saúde. Departamento de Vigilância das Doenças Transmissíveis. Manual de vigilância da leishmaniose tegumentar. Secretaria de Vigilância em Saúde, Departamento de Vigilância das Doenças Transmissíveis. Brasília, 2017, p. 189.

2. WHO. Leishmaniasis: epidemiological situation. World Health Organization. https://www.who.int/leishmaniasis/burden/en/. Accessed Mar 2020.

3. Almeida JV, Brazil RP. Retrospective study of cutaneous leishmaniasis in The State of Roraima, North of Brazil. Journal of Dermatology and Clinical Research 2017.

4. Negrão GN, Ferreira MEM. Considerações sobre a leishmaniose tegumentar americana e sua expansão no território brasileiro. Revista Percurso NEMO. 2014;1(6):147-68.

5. Athias $R$, Machado MA. Saúde indígena no processo de implantação dos Distritos Sanitários: temas críticos e propostas para um diálogo interdisciplinar. Cad Saúde Pública. 2001;17(2):425-31.

6. Gama Neto JL, Baima JM, Freitas RA, Passos MAB. Fauna flebotomínica (Diptera: Psychodidae) da Serra do Tepequém, Município de Amajarí, Estado de Roraima, Brasil. Rev Pan-Amaz Saude. 2010;1(2):131-6.

7. Brasil. Ministério da Saúde. Leishmaniose Tegumentar Americana - Casos confirmados Notificados no Sistema de Informação de Agravos de Notificação-SINAN EM Roraima entre os anos 2016 a 2018. www.saúde. gov.br.

8. Pezente LG, Benedetti MSG. Perfil epidemiológico da leishmaniose Tegumentar Americana no Estado de Roraima, Amazônia, Brasil, entre 2007 e 2016. Braz J Hea Rev 2019;2(3):1734-1742. Accessed Aug 2020.

9. Brasil. Constituição de 1988. Constituição da República Federativa do Brasil. Brasília: Supremo Tribunal Federal, Secretaria de Documentação, 2019, p. 577. Atualizada até a EC n. 105/2019. ISBN: 978-85-54223-41-0. www.stf. jus.br/arquivo/cms/legislacaoConstituicao/anexo/CF.pde. Accessed Sept 2019.

10. IBGE. Instituto Brasileiro de Geografia e Estatística. Estimativa populacional do Estado de Roraima, 2019. https://www.ibge.gov.br/pt/inici o.html. Accessed Sept 2019.

11. Schonian G, Nasereddin A, Dinse N, Schweynoch C, Schallig HD, Presber W, et al. Diagnóstico por PCR e caracterização de Leishmania em amostras clínicas locais e importadas. Diagn Microbiol Infect Dis. 2003;47:349-58.

12. GenBank. International nucleotide sequence database. https://www.ncbi nlm.nih.gov/genbank/. Accessed June 2020.

13. Sievers F, Wilm A, Dineen D, Gibson TJ, Karplus K, Li W, et al. Fast, scalable generation of high-quality protein multiple sequence alignments using Clustal Omega. Mol Syst Biol. 2011;7(539):1-6.

14. Paradis E, Schliep K. Ape 5.0: an environment for modern phylogenetics and evolutionary analyses in R. Bioinformatics. 2019;35(3):526-8.

15. Kamvar ZN, Tabima JF, Grünwald NJ. Poppr: an R package for genetic analysis of populations with clonal, partially clonal, and/or sexual reproduction. PeerJ. 2014;2:e281.

16. Jombart T. Aegenet: um pacote R para a análise multivariada de marcadores genéticos. Bioinformática. 2008;24(11):1403-5.
17. BioEstat 5.0. Download de Arquivos. http://www.mamiraua.org.br/ download/index.php?dirpath=./BioEstat\%205\%20Portugues\&order $=0$. Accessed Sept 2019.

18. Sampaio RNR, Gonçalves MC, Leite VA, França BV, Santos G, Carvalho MSL, et al. Estudo da transmissão da leishmaniose tegumentar americana no Distrito Federal. Rev Soc Bras Med Trop. 2009;42(6):686-90.

19. Coelho LIC, Paes M, Guerra JA, Barbosa MG, Coelho C, Lima B, et al. Characterization of Leishmania spp. Causing cutaneous leishmaniasis in Manaus, Amazonas, Brazil. Parasitol Res. 2011;108:671-7.

20. Naiff Júnior RD, Pinheiro FG, Naiff MF, Souza IS, Castro LM, Menezes MP, et al. Estudo de uma série de casos de Leishmaniose Tegumentar Americana no município de Rio Preto da Eva, Amazonas Brasil. Revista de Patologia Tropical. 2009;38:103-4.

21. Bacha HA, Tuon FF, Zampieri RA, Floeter-Winter LM, Oliveira J, Nicodemo AC, et al. Leishmania(Viannia) braziliensis identificação por PCR no estado do Pará Brasil. Transações da Royal Society of Tropical Medicine and Hygiene. 2011;105(3):173-8.

22. Araujo-Pereira T, Pereia DP, Moreira RB, Galdino TS, Duarte MPO, Brazil RP, et al. Molecular diagnosis of cutaneous leishmaniasis in an endemic area of Acre State in the Amazonian Region of Brazil. Rev Soc Bras Med Trop. 2018;51(3):376-81.

23. Da Silva ACT, Cupolillo E, Volpini AC, Almeida R, Romero GA. Species diversity causing human cutaneous leishmaniasis in Rio Branco, state of Acre, Brazil. Trop Med Int Health. 2006;11(9):1388-98.

24. Gama Neto JL, Baima JM, Freitas RA, Passos MAB. Fauna flebotomínica (Diptera: Psychodidae) em floresta preservada e alterada do Município de Caroebe, Estado de Roraima, Brasil. Rev Pan-Amaz Saude. 2012;3(2):41-6.

25. Souza AAA, Silveira FT, Lainson R, Barata IR, Silva MGS, Lima JAN. Fauna flebotomínica da Serra dos Carajás, Estado do Pará, Brasil, e sua possível implicação na transmissão da leishmaniose tegumentar americana. Rev Pan-Amaz Saude. 2010;1(1):45-51.

26. Barral A, Pedral-Sampaio D, Junior GG, Moem H, McMahon-Pratt D, Jesus $A R$, et al. Leishmaniasis in Bahia, Brazil: evidence that Leishmania amazonensis produces a wide spectrum of clinical disease. Am J Trop Med Hyg. 1991:44:536-46.

27. Lainson R, Shaw JJ. Taxonomy of the New World Leishmania species. Trans R Soc Trop Med Hyg. 1972;66(6):943-4.

28. Lainson R. Espécies neotropicais de Leishmania: uma breve revisão histórica sobre sua descoberta, ecologia e taxonomia. Rev Pan-Amaz Saude. 2010;1(2):13-32.

29. Guerra JAdO, Prestes SR, Silveira H, Coelho LIdARC, Gama P, Moura A, et al Mucosal Leishmaniasis Caused by Leishmania (Viannia) braziliensis and Leishmania (Viannia) guyanensis in the Brazilian Amazon. PLoS Negl Trop Dis. 2011;5(3):e980.

30. Vásquez A, Paz H, Alvar J, Pérez D, Hernández C. Informe Final: Estudos Sobre a Epidemiologia da Leishmaniose na Parte Ocidental da República do Panamá. Ministério da Saúde: Instituto Comemorativo Gorgas de Estúdio da Saúde; 1998.

31. Davies CR, Reithinger R, Campbell-Lendrum D, Feliciangeli D, Borges R, Rodriguez N. Epidemiologia e controle da leishmaniose nos países andinos Cafajeste. Saude Publica. 2000;16:925-50.

32. Lainson R, Braga RR, Souza AA, Povoa MM, Ishikawa EA, Silveira FT. Leishmania (Viannia) shawi sp. n., a parasite of monkeys, sloths and procyonids in Amazonian Brazil. Ann Parasitol Hum Comp. 1989;64(3):200-7.

33. Figueira LP, Zanotti M, Pinheiro FG, Franco AMR. Caracterização isoenzimática de isolados humanos de Leishmania sp (Kinetoplastida: Trypanosomatidae) dos municípios de Rio Preto da Eva e Manaus, Estado do Amazonas. Rev Soc Bras Med Trop. 2008;41(5):512-4.

34. Lainson R. Espécies neotropicais de Leishmania: uma breve revisão histórica sobre sua descoberta, ecologia e taxonomia. Revista PanAmazônica de Saúde. 2010;1(2):13-32.

35. Fagundes-Silva GA, Romero GAS, Cupolillo E, Yamashita EPG, Gomes-Silva A, de Guerra JAO, et al. Leishmania (Viannia) naiffi: rare enough to be neglected? Mem Inst Oswaldo Cruz. 2015;110(6):797-800.

36. Braga RR, Lainson R, Ishikawa EAY, Shaw JJ. Leishmania (Viannia) utingensis n.sp., a parasite from the sandfly Lutzomyia (Viannamyia) tuberculata in Amazonian Brazil. Parasite. 2003;10:111-8.

37. Cantanhêde LM, Mattos CB, Ronconi CS, Filgueira CPB, Júnior CFS, Limeira C, et al. First report of Leishmania (Viannia) lindenbergi causing 
tegumentary leishmaniasis in the Brazilian western Amazon region. Parasite. 2019;26:30.

38. Silveira FT, Ishikawa EAI, De Souza AAA, Lainson R. An outbreak of cutaneous leishmaniasis among soldiers in Belém, Pará State, Brazil caused by Leishmania (Viannia) lindenbergi n. sp., a new leishmanial parasite of man in the Amazon region. Parasite. 2002;9:43-50.

\section{Publisher's Note}

Springer Nature remains neutral with regard to jurisdictional claims in published maps and institutional affiliations.
Ready to submit your research? Choose BMC and benefit from:

- fast, convenient online submission

- thorough peer review by experienced researchers in your field

- rapid publication on acceptance

- support for research data, including large and complex data types

- gold Open Access which fosters wider collaboration and increased citations

- maximum visibility for your research: over 100M website views per year

At BMC, research is always in progress.

Learn more biomedcentral.com/submissions 